\title{
TREATMENT OF POSTERIOR GASTRIC WALL GASTROINTESTINAL STROMAL TUMOR WITH GASTRIC SLEEVE: A CASE REPORT
}

\author{
Daniel Navarini ${ }^{1,2,3}$, Antônio Benincá Albuquerque ${ }^{1}$, \\ André Luca Boeira Rovani ${ }^{1}$, Thiago Beltrame Rohden ${ }^{4}$, \\ Diego Reffatti ${ }^{2,3}$, André Emanuel Lunkes de Oliveira², \\ Christopher Naher'2, Felipe Baldus², Lais Antunes de Lima1', \\ Virgínia de Carli de Moura ${ }^{1}$, Felipe Thome dos Santos ${ }^{2}$, \\ Ramir Luan Perin ${ }^{2,3}$, Carlos Augusto Scussel Madalosso ${ }^{2,3}$
}

Clin Biomed Res. 2018;38(3):297-300

1 Faculdade de Medicina, Universidade de Passo Fundo (UPF). Passo Fundo, RS, Brasil.

2 Departamento de Cirurgia, Hospital São Vicente de Paulo (HSVP). Passo Fundo, RS, Brasil.

3 Departamento de Cirurgia, Clínica Gastrobese. Passo Fundo, RS, Brasil.

4 Faculdade de Medicina, Universidade Comunitária da Região de Chapecó (Unochapecó). Chapecó, SC, Brasil.

Corresponding author: Daniel Navarini danielnavarini@hotmail.com Faculdade de Medicina, Universidade de Passo Fundo (UPF)

Rua Teixeira Soares, 817. 99010-080, Passo Fundo, RS, Brasil. asymptomatic or present inconsequential symptoms such as abdominal pain (43\%), upper gastrointestinal bleeding (15\%) and palpable abdominal mass $(17 \%)$, in addition to chronic anemia ${ }^{5,6}$. They occur most commonly in men and after 50 years of age $^{5}$. Definitive diagnosis is based on immunohistochemical analysis of the surgical specimen, with search for the presence of CD117 receptors $(\mathrm{c}-\mathrm{kit})^{7}$. The gold standard treatment is surgical resection of the tumor with negative margins (RO), with no need for lymphadenectomy as lymph node involvement is very rare ${ }^{1}$. In cases of malignant GIST, recurrence or when there is no possibility of resection, imatinib mesylate, a tyrosine kinase inhibitor, can be used as a treatment option ${ }^{8}$.

\section{CASE REPORT}

A 53-year-old Caucasian man, ex-smoker, presented with history of gout and complained of melena and anemia, requiring blood transfusion. Hemoglobin level was $8.7 \mathrm{mg} / \mathrm{dL}$. Physical examination was normal. Upper digestive endoscopy demonstrated a lesion in the posterior gastric wall, in the antrum-body transitional zone, with a nodular formation of $5 \mathrm{~cm}$ adhered to deep structures, ulcerated and with recent signs of bleeding. An abdominal computed tomography (CT) scan identified a solid lesion in the gastric body compromising all the layers, measuring $6.4 \times 4.2 \times 4.1 \mathrm{~cm}$ (Figure 1). Based 
on endoscopic and CT findings, the diagnostic suspicion was gastric GIST. The patient underwent videolaparoscopy, which detected a tumor in the posterior wall of the gastric antrum, next to the greater curvature, with endophytic and exophytic growth. The chosen approach was gastric sleeve surgery. Calibration of the gastric tube was maintained with Fouchet probe, and the lesion was treated with full resection with negative margins, which was confirmed by intraoperative frozen section examination. The resected surgical specimen (Figure 2) was removed from the abdominal cavity through a small magnification of the right hypochondrium, using a specimen retrieval bag. Pathology examination revealed an oval cell tumor measuring $6.3 \times 4.5 \mathrm{~cm}$ and presence of three mitoses per 50 high-power field (HPF). No tumor necrosis or angiolymphatic and perineural invasion was identified, and the surgical limits were free of neoplasm. Metastasis was absent in seven resected perigastric lymph nodes. Tumor-free surgical margin measured $0.8 \mathrm{~cm}$. Immunohistochemical study was performed using the indirect immunoperoxidase method with diaminobenzidine. Microscopically, neoplastic cells exhibited positive antibodies for DOG1, c-kit (CD117) and Ki-67 (5\%). There were no positive antibodies for actina, desmina, CD34 and S100. Therefore, the diagnosis of GIST with fusocellular and epithelioid pattern was reached, with proliferative index of $5 \%$.

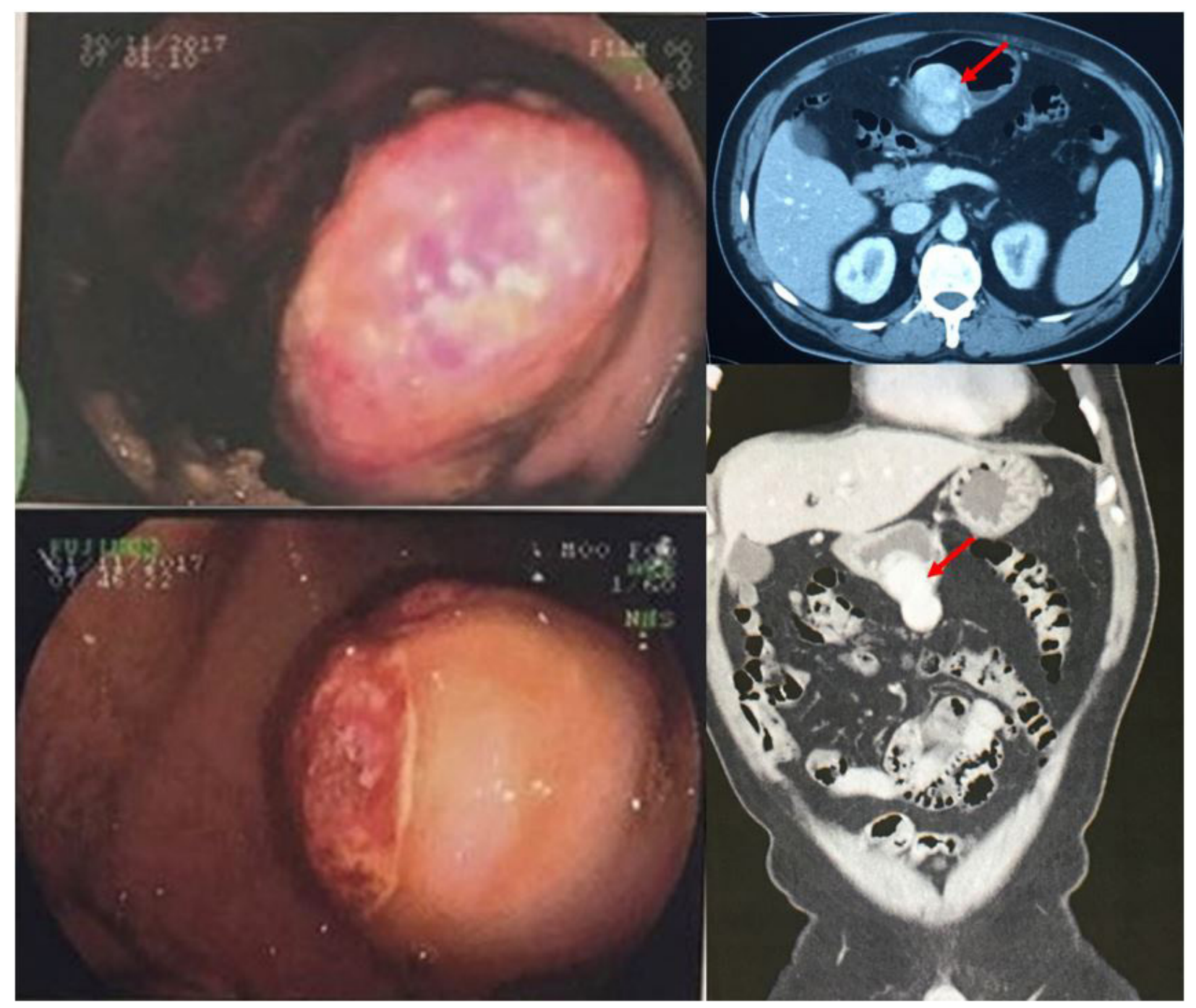

Figure 1: Upper digestive endoscopy and computed tomography scan showing a protruding, ulcerated lesion of the posterior wall of the gastric antrum. 


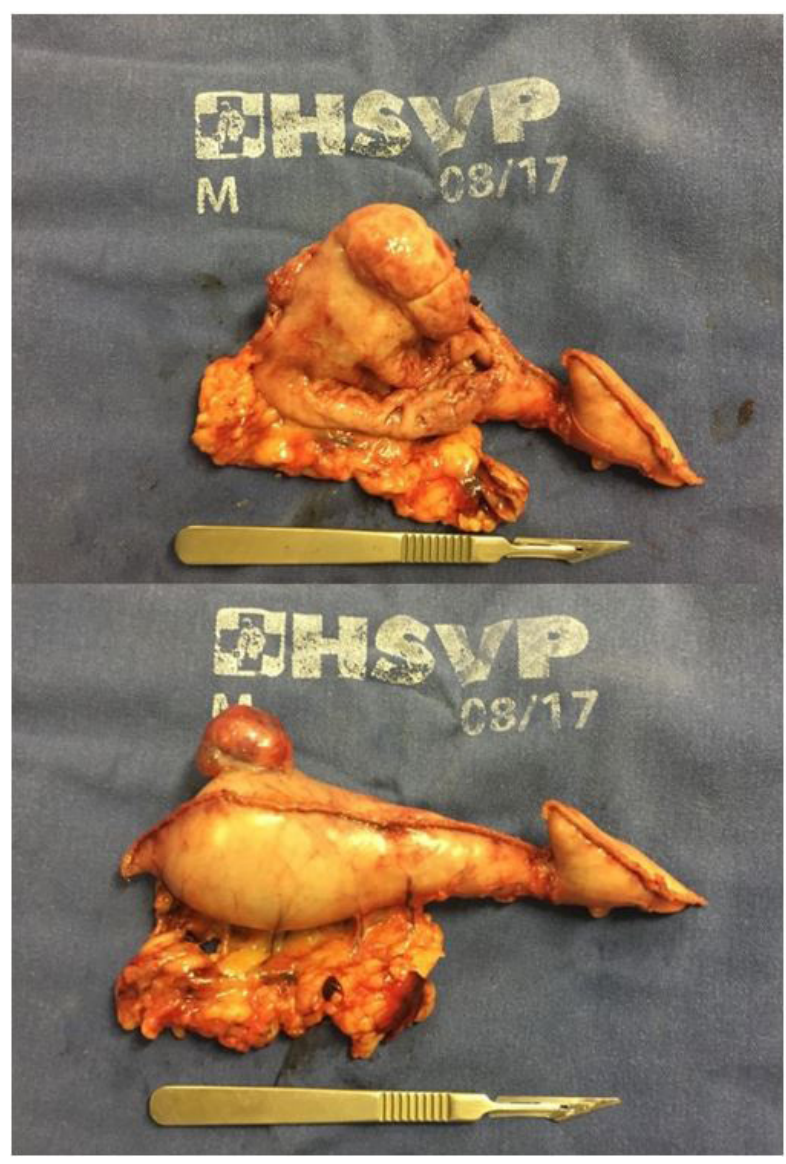

Figure 2: Resected lesion showing exophytic and endophytic growth.

\section{DISCUSSION}

GISTs may arise at any part of the $\mathrm{GIT}^{3}$ and at any age, with a higher incidence at 60 years. In addition, they affect men and women equally ${ }^{4,9}$. The main morphological parameters of differentiation of biological behavior related to malignancy and benignity are based on the size of the lesion and the number of mitoses per HPF ${ }^{5}$. Regarding immunohistochemical characteristics, CD117 protein, which is expressed in about $95 \%$ of GISTs, is helpful to differentiate them from other sarcomatous tumors of the GIT.
On CD117-negative lesions, the marker DOG1 is useful for diagnosis as it is detected in approximately $97 \%$ of the cases. Other immunohistochemical markers such as SMA, S100 protein, PKC theta and desmin are also helpful ${ }^{5}$. The gold standard treatment is surgical resection of the tumor with negative margins (R0). Lymphadenectomy is not required because longitudinal submucosal spread with consequent lymph node involvement is very rare ${ }^{1}$. In some restricted cases, neoadjuvant administration of imatinib mesylate can be used to induce downstaging and, consequently, to improve rates of $\mathrm{R} 0$ resections, disease-free survival and overall survival when compared to upfront surgery. Furthermore, adjuvant therapy with imatinib mesylate is indicated for specific cases, such as tumor measuring more than $5 \mathrm{~cm}$, more than 5 mitoses per $50 \mathrm{HPF}$, malignancy behavior, recurrence or when there is no possibility of resection ${ }^{10}$. With regard to the surgical technique, resection with a margin of $1-2 \mathrm{~cm}$ is usually recommended, although microscopic margins that are negative for tumor cells are sufficient for complete and curative resection ${ }^{11}$. During surgery, when removing the surgical specimen, caution should be taken in order not to cause tumor capsule rupture. In case of rupture, the disease progresses with peritoneal dissemination, given that there is a $100 \%$ chance of relapse, at least at the peritoneal level ${ }^{12}$. The surgical removal of the specimen must be done using a specimen retrieval bag in cases of videolaparoscopic approach, to avoid tumor capsule rupture inside the abdominal cavity. The surgical approach for the resection will depend on the tumor site. Typically, resections are easier in the stomach than in the duodenum due to the anatomic relationships with important structures ${ }^{1}$, for example. The prognosis of patients with GIST varies according to lesion location. Gastric lesions present the best prognosis, followed by small bowel, colorectal and extragastrointestinal GISTs ${ }^{13}$.

\section{Conflicts of Interest}

The authors declare no conflicts of interest.

\section{REFERENCES}

1. Hoeppner J, Kulemann B, Marjanovic G, Bronsert P, Hopt UT. Limited resection for duodenal gastrointestinal stromal tumors: surgical management and clinical outcome. World J

Gastrointest Surg. 2013;5(2):16-21. http://dx.doi.org/10.4240/wjgs.v5.i2.16.
2. Arellano-López PR, Solalinde-Vargas R, Guzmán-Mejía JI, GonzálezPérez LG, Zamora-García AC. Gastrointestinal stromal tumor of the stomach: case report. Rev Med Hosp Gen. 2017. In press. http://dx.doi. org/10.1016/j.hgmx.2016.12.001.
3. Chiang NJ, Chen LT, Tsai CR, Chang JS. The epidemiology of gastrointestinal stromal tumors in Taiwan, 1998-2008: a nation-wide cancer registry-based study. BMC Cancer. 2014;14(1):102. http://dx.doi. org/10.1186/1471-2407-14-102. 
4. Miettinen M, Lasota J. Gastrointestinal stromal tumors: definition, clinical, histological, immunohistochemical, and molecular genetic features and differential diagnosis. Virchows Arch. 2001;438(1):1-12. http://dx.doi. org/10.1007/s004280000338.

5. Rohde L, Osvaldt AB. Rotinas em cirurgia digestiva. 3. ed. Porto Alegre: Artmed; 2018.

6. Linhares E, Gonçalves R, Valadão $M$, Vilhena B, Herchenhorn D, Romano S, et al. Tumor estromal gastrointestinal: análise de 146 casos do centro de referência do Instituto Nacional do Câncer - INCA. Rev Col Bras Cir. 2011;38(6):398-406. http://dx.doi.org/10.1590/S010069912011000600006.

7. Bachet JB, Landi $B$, Laurent-Puig $P$, Italiano A, Le Cesne A, Lévy $P$, et al. Diagnosis, prognosis and treatment of patients with gastrointestinal stromal tumour (GIST) and germline mutation of KIT exon 13. Eur J Cancer. 2013;49(11):2531-41. http://dx.doi. org/10.1016/j.ejca.2013.04.005.

8. Gasparotto D, Rossi S, Campagna D, Scavina P, Tiziano FD, Marzotto $A$, et al. Imatinib-sensitizing kit mutation in a Carney-Stratakisassociated GI stromal tumor. J Clin Oncol. 2016;34(11):e99103. http://dx.doi.org/10.1200/ JCO.2012.44.7300.

9. Miettinen M, El-Rifai W, Sobin LH, Lasota J. Evaluation of malignancy and prognosis of gastrointestinal stromal tumors: a review. Hum Pathol. 2002;33(5):478-83. http://dx.doi. org/10.1053/hupa.2002.124123.

10. Ozkan EE. Radiotherapy for gastrointestinal stromal tumors. Chin Med J. 2018;131(2):235-40. http://dx.doi.org/10.4103/03666999.222344.
11. Naguib SF, Zaghloul AS, Marakby HE. Gastrointestinal Stromal Tumors (GIST) of the Stomach: Retrospective Experience with Surgical Resection at the National Cancer Institute. J Egypt Natl Canc Inst. 2008;20(1):80-9.

12. Poveda A, del Muro XG, LópezGuerrero JA, Martínez V, Romero I, Valverde C, et al. GEIS 2013 guidelines for gastrointestinal sarcomas (GIST). Cancer Chemother Pharmacol. 2014;74(5):883-98. http:// dx.doi.org/10.1007/s00280-014-25470 .

13. Zhang Q, Shou $\mathrm{CH}$, Yu JR, Yang WL, Liu XS, Yu H, et al. Prognostic characteristics of duodenal gastrointestinal stromal tumours. $\mathrm{Br}$ J Surg. 2015;102(8):959-64. http:// dx.doi.org/10.1002/bjs.9831.

Received: Feb 8, 2018 Accepted: June 19, 2018 